\title{
The Papal Network: How the Roman Curia Was Informed about South-Eastern Europe, the Ottoman Empire and the Mediterranean (1645-1669)
}

\author{
Johann Petitjean
}

Known at the time as Candia, after the former name of its capital city, Crete is the oldest colony of the Venetian Dominion. ${ }^{1}$ The island was considered more of a burden than an asset to the Venetian economy, and indeed its commercial importance diminished after the loss of the ports of Modon and Coron, and the redirection of goods to the benefit of Zante (Zakynthos) and Corfu. ${ }^{2}$ Nonetheless, it remained a symbolic jewel of the Venetian Dominion in the middle of the seventeenth century. After the loss of Cyprus, taken by the Ottomans in 1573, Crete was the Most Serene Republic's only significant colony in the Eastern part of the Mediterranean. As an essential stop on the maritime route from Istanbul to Alexandria, it was coveted by the Ottomans, who perceived Venetian control over the island as an obstacle to their Mediterranean policy, even as an anomaly, since the safety of the Ottoman merchants sailing in the Levant could not be guaranteed as long as Christian corsairs could rely on the Cretan ports to provide them with optimal conditions to lead their seasonal campaign. ${ }^{3}$ Moreover, Maltese activity in the Eastern Mediterranean

1 The island became a part of the Venetian Dominion after the fourth crusade and the disruption of the Byzantine Empire. See Mario Gallina, Una società coloniale del Trecento: Creta fra Venezia e Bisanzio (Venice: Deputazione di Storia Patria, 1989), and Democratia Hemmerdinger Iliadou, 'La Crète sous la domination vénitienne et lors de la conquête turque (1322-1684). Renseignements nouveaux ou peu connus d'après les pélerins et les voyageurs', Studi Veneziani, 9 (1967), pp. 535-623. This paper was presented at the News Networks in Early Modern Europe workshop in Rennes (10 May 2012) before being developed, in French, as the last chapter of my book, Lintelligence des choses: une histoire de l'information entre Italie et Méditerranée, XVI ${ }^{e}-X V I I^{e}$ siècle (Rome: École française de Rome, 2013).

2 Benjamin Arbel, 'Riflessioni sul ruolo di Creta nel commercio mediterraneo del Cinquecento', in Venezia e Creta. Atti del convegno internazionale di studi, ed. Gherardo Ortalli (Venice: Istituto veneto di scienze, lettere ed arti, 1998), pp. 245-59.

3 Molly Greene, A Shared World: Christians and Muslims in the Early Modern Mediterranean (Princeton: Princeton University Press, 200o), pp. 13-17; Suraiya Faroqhi, The Ottoman Empire

(C) JOHANN PETITJEAN, 2016 | DOI 10.1163/9789004277199_008

This is an open access chapter distributed under the terms of the Creative Commons Attribution-

Noncommercial-NoDerivatives 3.o Unported (CC-BY-NC-ND 3.o) License. 
was the excuse taken by Ibrahim I to send a task force to Crete, thus triggering a 24-year imperial war. ${ }^{4}$

The main events of this war are well known to historians, mostly through some reports and chronicles published in Europe as soon as the troops returned home. The war was not limited to the island itself, however, and contrary to what the titles of many articles and several well-known books on the subject suggest, the conflict did not simply come down to the events that happened in 1667-9. During the 1650s, it spread to the Dardanelles, the Aegean islands, and also Dalmatia as well as Morea, as Lazzaro Mocenigo attacked Chios in 1657, and Francesco Moresini took Kalamata the year after. The entire conflict tends to disappear in the shadow of the two last years of siege, in the same way as, on another scale, the battle of Lepanto often stands for the War of Cyprus, the Turkish War or even all of Mediterranean history. Despite military specialists' fascination for the siege itself, the persistent interest of historians_-predominantly French-in the expeditions of the so-called 'Volunteers' enlisted to fight 'the Turk' on Cretan beaches, and all the studies dedicated to the diplomatic moves and alliances caused by the conflict, there are still far fewer publications dealing with the Cretan War than the War of Cyprus. ${ }^{5} \mathrm{~A}$ few episodes are better known, and the list of these clearly shows that news was far more widely spread when it was good, that is to say, when there was something to celebrate. During the last years of the siege of Candia, however, after the pope decided to commit men and means to help the Venetian armies overwhelmed by the besieging Ottoman troops, it appears that a brand new information policy was implemented, based on the addition and maximisation of pre-existing tools.

An extensive study of the Cretan War, based on the original documentation in the Vatican, allows us to reconstitute the varied circuits that conducted Mediterranean news to Rome, to identify who the 'Popes' men' were in the area and how they collected and transmitted the news in the specific context of the long and decisive crisis of the Cretan war. ${ }^{6}$ The necessarily composite nature of the wide pontifical web dedicated to keeping strategic watch on the Ottoman empire and, at that time, to tracking military operations both on the island and

and the World Around it (London: г в Tauris, 2006), p. 51; Michel Fontenay, 'L'Empire ottoman et le risque corsaire au XVII ${ }^{\mathrm{e}}$ siècle', Revue d'Histoire moderne et contemporaine, 32 (1985), pp. $185^{-208 .}$

4 See Gino Benzoni, 'Morire per Creta', in Venezia e Creta, pp. 151-73.

5 See for instance Özan Badrakci and François Prugnière, La Dernière croisade. Les Français et la guerre de Candie, 1669 (Rennes: Presses Universitaires de Rennes, 2008).

6 The expression comes from Peter Partner, The Pope's Men: The Papal Civil Service in the Renaissance (Oxford: Oxford University Press, 1990). 
in the Balkans, is expressed at the level of spaces, time, institutions, actors, channels and media. It exposes a radical ordered heterogeneity that invites us, in the first place, to consider the papal networks in the early modern Mediterranean as a phenomenon that extends beyond the diplomatic framework, and, secondly, to rethink the institutions through their practices, and the 'international politics' through the information processes. ${ }^{7}$

\section{The Nuncio, Official Agent in Venice and Regional Information Coordinator}

The cornerstone of the whole system indeed remains the diplomatic relations with Venice. In the middle of the seventeenth century, it was still thanks to the Pregadi that the nuncio was directly and continuously informed about facts and events that the Venetian government also shared with the pope through its ambassadors in Rome. The coded notes of the archbishop of Athens, Monsignor Jacopo Altoviti, show a nuncio extremely busy with the audiences he attends, accompanied by one of his assistants who takes notes about the dispatches, or rather the small abstracts and excerpts that the Senate makes available to the pope. ${ }^{8}$ There are fixed hours and days for ordinary audiences, but the nuncio is sometimes woken up in the middle of the night for an unexpected interview - as happened to Monsignor Caraffa, Altoviti's predecessor, once woken up at 3 a.m. to receive news from Dalmatia, the Greek Islands, and the Ottoman capital city; news of little interest, as it turned out, and probably intended more as just retribution for the nuncio's insistence on being kept informed of everything, all the time. ${ }^{9}$

The fact that Borghi or Ciampoli, the nuncio's secretaries, actually attended the audiences helps us understand how their reports can be as precise and detailed as they are. ${ }^{10}$ Besides, the fact that an official sheet summarising everything judged important by the Savi was also sent or given at the end of the audience explains why the 'public' letters, that is to say the official letters,

7 For a general account of the institutions, means and goals of the papal diplomacy, see Pierre Blet, Histoire de la Représentation diplomatique du Saint Siège (Vatican City: Archivio Vaticano, 1982); and Maria Antonietta Visceglia, ed., Papato e politica internazione nella prima età moderna (Rome: Viella, 2013).

8 Franco Gaeta, 'Altoviti Iacopo', in Dizionario biografico degli Italiani (hereafter DBI), 2 (1960), pp. 576-7.

9 Archivio Segreto Vaticano (hereafter Asv), Segr. Stato, Venezia, 9o, 8, 7 July 1657.

10 For example: Asv, Segr. Stato, Venezia, 282, 71-2, 12 July 1659. 
are so numerous in the Roman archives. If we compare systematically all the letters sent to Rome by the apostolic nunciature of Venice from $1645^{-57}$ and 1657-9 with those sent from $1570-72$, those dealing with the War of Crete are much easier to follow than those from the Cyprus campaigns. Of course, the places where the Ottoman troops actually engaged the Venetian army-soon joined by the Papal forces, the Maltese, and numbers of mercenaries and young European nobles who cherished the spirit of the Crusade - are much closer to the Italian Peninsula than had been the case in the previous conflict. But this proximity of the theatres of operations, as real as it is, is not in itself decisive. More important was the conflict's breaking out into three different combat zones (Crete, the Dardanelles and Dalmatia) and their proximity to Venetian maritime bases and allies.

The information about the Veneto-Ottoman War of $1645^{-69}$ is not as massive and continuous as it may seem at first: if there is in fact a real quantitative change, it is only based on the conjunction of two factors that have nothing to do with any qualitative revolution in the Serenissima's networks in the Mediterranean. The apparent amount of news transmitted and received during the conflict, often on a weekly basis, does not mean that this war was judged more important than the previous one. From $1645^{-7}$, the volume and frequency of the military news bulletins reaching the Apostolic nuncios is comparable with the reporting of the Cyprus war; but ten years later, during the second phase of the conflict, it doubles or even triples. Fields of operations are more numerous, closer to the peninsula, and related to places administered or frequented by the agents of the Serenissima. The reason for the change lies mainly in the conjunction of the geopolitics of the war, and the geography of the Venetian overseas dominions. This geographical politics was also a potential commercial and informative geography of the Mediterranean since the Venetian possessions were used as observatories and relays for the transmission of maritime news. It is apparent in an avviso of 6 October 1646 which mentions the disappointment of the Venetian authorities when a ship just arrived from Smyrna was unable to provide any information, since it had not stopped in Crete, nor in Zante or Cephalonia, nor even in Corfu. ${ }^{11}$ The Ionio-Aegean area played a structuring role in the transmission of Cretan news to Venice.

To complete the lists of the islands and stops previously cited, we should add Cythera, through which the General Grimani's letters passed at the end of August $1646 .{ }^{12}$ To this first group of places must be added a second, on the

\footnotetext{
11 ASv, Segr. Stato, Venezia, 71, 512-5.
}

12 ASv, Segr. Stato, Venezia, 71, 461-4. 
Adriatico-Balkanic side, comprising Kotor, Ragusa and Durres (in descending order of importance) which transmitted news from the continental part of the Ottoman Empire in times of war, a role normally assigned in peacetime to the fregata that regularly sailed from Istanbul to Venice. From 1645 on, the 'letters from Constantinople' indeed get particularly scarce, and since the bailo was reduced to silence, the Venetian authorities had to solicit other ambassadors. ${ }^{13}$ Soranzo succeeded in communicating with his government in April 1646 by enclosing a letter of his own in the mail sent by the French ambassador on a boat unofficially chartered by French merchants. ${ }^{14}$ Matters did not improve when the second phase of the conflict began in 1657: for two whole years, the Republic of Venice was left without the slightest 'public letter' and had no other choice but temporarily to replace avvisi with rumours. ${ }^{15}$

Although the Serenissima, in her quest for allies, clearly made an effort to communicate more news than before, and although there was a regularisation of the flow of news between the Mediterranean and the Peninsula, the official ways for transmitting information remain unsatisfactory in many aspects. The Apostolic nuncios, as well as their correspondents, the Secretaries of State and the pope's nephews, who also have access to news of Levantine affairs through the audiences given to the ambassadors in Rome, and who share the central coordination of the popes' networks and manage the news according to topic, geographical origin, and/or institutional type and degree, are products of their time: they became used to receiving a quantity of news each week which was incomparably larger than what was delivered during the War of Cyprus. Their expectations and needs evolved with the situation and grew as new media and geopolitical potentialities were tested. In this regard, the experience of information appears to be structurally unsatisfactory.

So, as early as the summer of ${ }_{1645}$, we find Angelo Cesi, bishop of Rimini, adding more confidential information to the official news. ${ }^{16}$ The nunciature had its own agents in Venice, able to transmit information held or hidden by the government. On 1 July, for example, most of the news from Istanbul given by the nuncio had been communicated to him "by a person very well informed of the things going on in the Palace", and by another "friend" who, in the official mail freshly arrived from Kotor, had "seen" a letter from the Venetian bailo's

13 For more information about Venetian diplomats in Istanbul, see Eric R. Dursteler, 'The Bailo in Constantinople: crisis and career in Venice's early modern diplomatic corps', Mediterranean Historical Review, 16.2 (2001), pp. 1-30.

14 Dursteler, 'The Bailo in Constantinople', p. 285.

15 Andrea Valiero, Historia della guerra di Candia (1679; Trieste, 1859), pp. 488-9.

16 Gino Benzoni, 'Cesi Angelo' DBI (24, 1980), p. 241. 
butler confirming the news given by the first informer. ${ }^{17}$ Since Cesi had only been in Venice for two months at that time, we may assume that he inherited the networks of his predecessors and redirected them toward Ottoman questions. The Venetian "friends" of the nunciature allowed access to news where disclosure was delayed or even forbidden. Spying was a way to circumvent these practices and, mostly in the former case when the news was only delayed, an accelerator, the best way to avoid simply submitting to the tempo imposed by the Venetian government. The arrival of mail from Istanbul or from the armies appears to have been an event in itself: it could not be kept hidden for long from the main persons interested in it. For financial as well as diplomatic reasons, the nuncio's spies could not be perpetually active, but rather were called upon occasionally, depending on the arrival of letters and the degree of delay in normal and official communication. At the beginning of 1646, news became particularly scarce, and Monsignor Cesi was led to present his excuses several times for the paucity of the avvisi he was able to supply to the Holy See. ${ }^{18}$ When letters from the Levant finally reached Venice in midFebruary, the nuncio took them as a sign that the information winter had finally come to an end. So he rejoiced and waited to be called in. But time went by and nothing was disclosed. The nuncio finally lost patience and talked to the Secretary, who confirmed that nothing had been divulged in Rome either, reluctantly announcing the measures to be taken. Spying on an ally is clearly not an easy decision to make, but after two weeks of silence, the nuncio considered that the contract had been broken. Since dissimulation was contrary to the rules of diplomacy, they could be considered as temporarily suspendedwhich allowed and even justified spying, interpreted as a perfectly legitimate course of action under the circumstances, and always an extraordinary measure.

From 1658 on, the nunciature acquired another secondary, but also most probably confidential, source of information on what happened in Istanbul, the European and continental parts of the Ottoman Empire. This source was

\footnotetext{
17 "Nella materia del turco hieri fui avvisato da persona, che svole esser molto ben informata delle cose di Palazzo, e mi disse, che le lettere di Costantinopoli portorono, che'l Visir mandò à chiamare il Dragomano mag[gio]re del Bailo, e gli domandò, se che nova havea il Bailo, della Sua Armata, e rispondendoli, che nessuna, domandò di nuouo, e della nostra sapetene niente e negando questo parimente soggiunse, se il Bailo havea amor nessuno, rispose l'altro, che timor potea havere, se non havea guerra, et era assicurato dalla buona volontà del Re mediante la parola di $S[u a] E c c[e l l e n z]$ a che direbbe disse, se andassimo à Corfü, rispose, che non potea crederlo stante la parola di $S[u a] E c c[$ ellenz $] a$ ", in ASv, Segr. Stato, Venezia, 69,30 and 32. 
the Baron Taxis, the Emperor's post-master, who allowed the nuncios Caraffa and Altoviti access to his own networks in Vienna and Eastern Europe, which were used on the one hand to compensate for the diminution of the numbers of 'letters from Constantinople' while the bailo was under surveillance, and on the other hand to counterbalance the monopoly of the Serenissima on the little Ottoman news still reaching Venice. ${ }^{19}$ This may seem trivial, and risky too, for the Holy See, compared to the practices and tactics of Facchinetti, the papal nuncio during the War of Cyprus. ${ }^{20}$ So it would be easy to jump to the conclusion that the nuncios considered themselves happy with the data delivered by the Venetian government, or were at least resigned to their inability to find a durable source of information to replace it. But this would be to forget that the orientations of the nunciature only make sense in the broader context of the general information policy conducted by Rome. In a nutshell, just because the Roman authorities reacted poorly to the Venetian tactics and felt the lack of information throughout the Cretan conflict, it does not follow that they were satisfied with them. On the contrary, this sort of resignation may be interpreted as proof that, between the two Veneto-Ottoman wars, the Roman Curia freed itself, at least partly, of Venice's grip on Levantine news. It should be noted that the news the Venetian government granted to its allies during the war was meant to serve the geopolitical interests of the Republic by convincing the Princes to take part in the conflict. The number of Venetian documents enclosed in the mail of the nunciature, or transmitted by the Venetian ambassadors in Rome, is quite impressive. It even grows notably after 1657 , even though some of these ambassadors were known for their anti-ecclesiastic positions - as the Cavalier Iacomo Quirini, who caused the Pope Chigi "a particular aversion". ${ }^{21}$ Numerous military reports are produced at that time, and handwritten copies of them are distributed, probably by the Venetian government itself. ${ }^{22}$ Since the quantity, and quality, of data communicated were directly related to the geopolitical goals of the Serenissima, they varied according to the context, whether the aim was to interest the pope in the destiny of the Dominion, or negotiating with the Sultan.

19 For instance: "Da Vienna con lettere delli 13 del cadente scrive à questo Sig[no]r Barone Tassis un' suo Corrispondente, che teneva avvisi freschissimi d'Andrinopoli (Edine), che essendosi il Valacco opposto con $25 \mathrm{~m}$ [ila] huomini al Bassà di Silitria numeroso di $50 \mathrm{~m}$ [ila] trà Turchi et Tartari, questi l'havessero rotto con morte di ottomila de suoi ...", Asv, Segr. Stato, Venezia, 91, 269, 27 April 1658.

20 See Petitjean, L'intelligence des choses, pp. 247-77.

21 Asv, Segr. Stato, Venezia, 282, 'Prefazione', 6.

22 Mostly in Biblioteca Apostolica Vaticana (hereafter BAV), Barb. Lat., 5124-5, 5136, 7806; and ASv, Segr. Stato, Avvisi, 41. 
Some of the documents enclosed in the nuncios' mail were official not because of who wrote them, but because of the way they were transmitted and, above all, how they were treated in chancellery before being sent inside and outside the government. On 4 August 1657, for example, after exposing the main affairs and negotiations treated by the nunciature, the apostolic agent proceeded to select the news he had received during the week. This includes the seizure of Chios by Venetian troops, but, what with the news coming from Livorno and not directly from the Adriatic Sea and, moreover, with no confirmation after almost 50 days, the nuncio considers it "groundless". ${ }^{23}$ Before closing his weekly mail, he added a last document, a letter from Kotor, the Venetian outpost in the Balkans besieged by the Ottoman troops in 1657, signed by a merchant named Giovanni Bolizza, who provided him with some details about the fights between the fleets in June. ${ }^{24}$ In 1657 , as ten years earlier, the Republic's information policy was based on the desire to call upon her allies for help, which explains why the doctrine and rhetoric of the common enemy met with real success at this time, (re)activating Christian networking in the Mediterranean and in south-east Europe for the benefit of the Roman Curia.

\section{Papal Assets in the Mediterranean: A Configuration}

Many among those involved from the beginning on the various Levantine front lines occasionally but directly informed the pope, the cardinal-nephew, or the Secretary of State. For example, Giuseppe Peruzzini Anconomitain, enrolled in the Venetian army under the command of the Marquis de Ville, offered to send Cardinal Rospigliosi news of the conflict through the mail of the Pontifical regiments. ${ }^{25}$

Bishops and missionaries in the Balkans also informed the Roman authorities of the state and progress of the Ottoman troops in the region via the nuncio of Venice or the prefect of the Congregation De propaganda Fide. ${ }^{26}$ The 644 documents edited by Marko Jačov clearly shows that missionaries and ecclesiastic delegates not only sent documents concerning the religious and administrative

\footnotetext{
23 Asv, Segr. Stato, Venezia, 90, 119 .

24 ASV, Segr. Stato, Venezia, 90, 102.

25 BAV, Barb. Lat., 7806, 89-96.

26 See Giovanni Pizzorusso, 'Per servitio della Sacra Congregatione de Propaganda Fide: i nunzi apostolici e le missione tra centralità romana e Chiesa universale (1622-166o)', in Ambasciatori e nunzi. Figure della diplomazia in età moderna, ed. Daniela Frigo, Cheiron, 30 (1999), pp. 201-27.
} 
lives of their dioceses to Rome and Venice, but also collected and transmitted first-hand military information to the Holy See. On 2 February 1646, for example, the Bishop of Nin, leaving for Rome, describes the military incursions of the Ottoman army in his diocese; the day after, friar Anton Francesco Orasti seized the 'occasion' to inform the Congregation that the Pasha of Bosnia, with 'more or less' 15,000 men, was marching on Sibenik. ${ }^{27}$ Missionaries and bishops also wrote newsletters. Details of troops entering the dioceses of Zadar and Nin, ravages perpetrated in the diocese of Kotor, the use of canons against Novigrad in July 1646 and the fall of the city are all to be found in newsletters supplied by ecclesiastical correspondents. The whole Balkan campaign was closely followed by the missionaries and religious authorities present in the area. ${ }^{28}$ After 1648 and the seizure of the fortress of Klis, however, newsletters became less frequent, though data still flowed, albeit infrequently, without interruption for the duration of the war.

The Ragusan government secretly, but continuously, sent many newsletters to Naples from the mid-sixteenth century, and to Rome since the end of the Cyprus war, at that time using the name of Lucio Pisone. ${ }^{29}$ However, it is only during the first years of the Cretan war that this noteworthy Balkan circuit begins to run at top speed. On 14 April 1645, while the Ottoman authorities tightened their controls on the post services and agents of the tributary Republic, the name changes to Martino da Turra. ${ }^{30}$ The newsletters discreetly transmitted by the Ragusan authorities thanks to these aliases principally dealt with the situation in the empire and the main events in Istanbul: the government placed its resources, the merchant and diplomatic networks in the Ottoman empire, at the pope's and Viceroy's disposal, giving them the means

27 Marko Jačov, ed., Le missioni cattoliche nei Balcani durante la guerra di Candia (1645-1669) (Vatican City: BAV, 1992), vol. 1, pp. 38-40.

28 Jačov, Le missioni cattoliche, $1: 50-3$.

29 For more information about this particular part of the papal news network and backchannel diplomacy in Europe and the Mediterranean, see Johann Petitjean, 'On His Holiness' Secret Service: How Ragusa became an Intelligence agency after Lepanto', in Europe and the Ottoman world: Exchanges and Conflicts (16th-17th centuries), ed. Gabor Karman and Radu G. Paun (Istanbul: Isis, 2013), pp. 83-106.

30 "Di V[ostra] Santità alla quale ricordo, che da hora in avvenire quel che mi occorrerà di servirle le scriveró sotto questo nome, cioè Martino de Turra, e cosí si compiacerà V[ostra] $B[$ eatitudi]ne di chiamarmi nel rescrivermi, perchè per degni rispetti ho rissoluto di mutare il mio nome di Lucio Pisone, nel detto di Martino de Turra”, Ivan Dujčev, Avvisi di Ragusa: documenti sull'impero turco nel sec. XVII e sulla guerra di Candia (Rome: Pont. institutum orientalium studiorum, 1935), 15. Originally in ASV, Segr. Stato, Particolari, 19, 4-5, 14-20 April 1645. 
of keeping a cautious eye on lands where these two powers had no official agent and thus no constant network. With the beginning of the war, the Ragusan antennae were directed towards the Balkans in order to follow troop movements and battles in the region without depending on Venetian reports. Between 1574 and 1663, more than 200 Ragusan newsletters reached Rome and were processed by the cardinal-nephews, particularly during the tenures of the Barberini, Maffeo and then Francesco, as 'protectors' of the city. ${ }^{31}$ From 1606 to 1644, approximately two letters were sent each year, but six reached Rome in 1621 and 1635, while the sultan's troops were attacking Poland. In 1645-7, the proportions are incomparably greater: more than 50 newsletters were sent, providing the pope with an unprecedented amount of data.

Because of the annual naval campaigns of the Knights of St John and the naval traffic between the western and the eastern part of the Mediterranean sea, and, later, thanks to the Inquisitor and Apostolic Delegate sent to the island and the Grand Master, the pope kept an eye on the Levant and the ongoing events of the Cretan war from Malta. From the end of winter 1645, the Inquisitor's correspondence notably neglected the local news, its chief preoccupation up to that point, to focus on the Levant, which proves that the pontifical 'sensor' in Malta could be relatively efficiently re-oriented according to the global situation and the needs, explicit or not, of the State Secretary, the Curia and the pope.

Monsignor Gori's correspondence, like those of Antonio Pignatelli and Carlo Cavalletti after him, is full of data brought by the Maltese exploratores during the annual campaigns of the fleet, or the sailors and captains of merchant ships stopping at the island. ${ }^{32}$ Central Mediterranean navigation and intelligence missions organised by the Knights in the Levant complete the strictly local or regional news in both the dispatches and the Avvisi di Malta the Inquisitors sent to Rome. The former mostly dealt with the administration of the nations of the Order and the ongoing negotiations between Rome and the Grand Master, the latter with the state of maritime traffic and the activity of Barbary corsairs in the Central Mediterranean. News became more frequent after the arrival of Monsignor Carlo Cavalletti on the island in May 1648. New contacts were made, old ones were reactivated on the fringes of the Eastern Mediterranean, and they all began to be productive. From 1649 onwards that the missives of the Inquisition began to contain (in addition to the official dispatches) copies of the

\footnotetext{
31 'Ragusa. Il Card[inale] Maffeo Barberini fu protettore di quella Republica. Assunto al Pontificato, il Card[inale] Francesco successe alla protezione', BAv, Barb. Lat., 7809, s.n.

32 Paolo Piccolomini, 'Corrispondenza tra la Corte di Rome e l'Inquisitore di Malta durante la guerra di Candia (1645-1669)', Archivio Storico Italiano, 41.1 (1908), pp. 67-70.
} 
avvisi that the correspondent of the Sovereign Order transmitted to the Knights and the Grand Master then communicated to the Apostolic Delegate to inform the pope via the cardinal-nephew Camillo Pamphili (until he renounced his cardinalate to marry Olimpia Aldobrandini) the correspondence being handled by the Secretariat of State. In that year, most of the data was primarily assembled in Zante before being communicated to Malta and then on to Rome. An important example would be the news of the Turkish fleet crossing the Dardanelles on 3 May 1649. The news, probably sent by Iacopo Riva, the then leader of the expedition to the Turkish Straits, came first to Candia and reached Zante 14 days later; it was forwarded on 28 May by a certain Giorgio Latino, whose letter of avvisi was enclosed in the first mail sent by the new Inquisitor from Malta on 14 July. ${ }^{33}$ Giorgio Latino, who might have worked in Zante as a chargé d'affaires, is the only informer openly named in the letters of the Inquisition. Although his epistolary activity can be identified as early as 1631, it grew more frequent with the war. Above all, it relayed relevant and precious information: Giorgio Latino, it would seem, was the first to tell the Knights about military preparation in the Ottoman empire, and also revealed the destination of the sultan's galleys stationed at Navarino. ${ }^{34}$ When the Pontifical regiments did not put to sea with the Maltese to go to Crete, or the Dardanelles, to assist the Venetian troops, the Holy See lost a direct source of information on the conflict, thus intensifying the influence of peripheral various observatories, giving more importance to the Inquisitor's letters. However, from 1658 to 1660 , Crete does not seem to have been a priority. While Alexander VII (Fabio Chigi, 1599-1667) and the Curia seemed mostly preoccupied with what was happening on the other side of the Alps, and while the Ottomans focused on Transylvania, the Knights of the Sovereign Order rarely left the Central Mediterranean, fighting mostly with corsairs from North Africa. News from the front line became scarce, and was therefore notably replaced by regional or local news until 1667 ; that is, while the siege of Candia moved into its decisive phase and Clement Ix (Giulio Rospigliosi, 1600-1669) substituted for Alexander VII at the head of the Church.

The role of the nephew Iacopo Rospigliosi (1628-84) at the Curia was highly strategic. As Surveyor of the Ecclesiastic States, he was held in high esteem by his uncle whom he assisted in Madrid, and who did not forget the virtues of nepotism he observed during the times of Urban VIII, when he learned the mechanisms of the Pontifical Curia alongside Antonio Barberini. ${ }^{35}$ His correspondence

\footnotetext{
33 Piccolomini, 'Corrispondenza', pp. 105-7.

34 Piccolomini, 'Corrispondenza', p. 114.

35 About the Rospigliosi family, see Gaetano Moroni, 'Rospigliosi, famiglia' and 'Rospigliosi Jacopo, Cardinale', in Dizionario di erudizione storico-ecclesiastica, 59 (1852), pp. 161-9;
} 
with his brother Vincenzo Rospigliosi, in place of Decio Azzolino or in conjunction with the action of the Secretary of State, depending on the subject matter and/or circumstances, is without doubt one of the most critical. On 27 July and 2 August 1668 for instance, as the Pontifical naval force commanded by the frà Rospigliosi lay close to St Theodore, Vincenzo completed the reports concerning his squadrons with some news about the siege, given to him by the Venetians who joined him, and reported things that the Venetian Commissioner of Souda had apparently learned by questioning "a few Greeks". ${ }^{36}$ However, despites this kind of efficient Roman-Venetian joint intelligence, despite the cardinal nephew's commitment and power, and in spite of Vincenzo's efforts and application in following his predecessors' example, the news did not always arrive in time. The Ionian Islands represent a strategic point, beyond which news communication became unreliable and journeys so much longer and more hazardous that solutions had to be found. Pontifical troops, Maltese and Venetians continued to communicate and exchange news about the different fleets and the places where the conflict was still raging. And when the information transmitted by one command to another was considered important enough, the Pontifical General forwarded it at once to the cardinal. Means of communication were also pooled by the allies: thus, just before leaving St Theodore where he spent almost one month after bombing it at the beginning of July 1668 , Rospigliosi, albeit slightly reluctantly, decided to use the Serenissima's communication and resources to send his last letters in Italy. ${ }^{37}$

From May 1668 on, Iacopo Rospigliosi gained another source on the progress of the siege thanks to "an agent of His Catholic Majesty on duty on this island [of Zante] for the Levantine Intelligence" while the Cretan news reaching Rome through normal channels of communication, that is to say mostly through agents in Venice and Napoli, was still received by the Secretariat of State, and processed by its agents. ${ }^{38}$ Thus, the nature of the data does not help us to understand how tasks were divided between the two main associates of Pope Clement IX. The nephew and the Secretary both received dispatches and letters of avvisi dealing with the war, processed the main information with

Vittorio Capponi 'Rospigliosi, famiglia', 'Rospigliosi Giulio' and 'Rospigliosi Iacopo', in Biografia pistoiese, o Notizie della vita e delle opere dei pistoiesi (Bologna: tip. Rossetti, 1878; Bologna, 1972 ), pp. 336-41; Raoul Meloncelli, 'Clemente IX', DBI, 26 (1982), pp. 282-93.

Franco Ballerini, 'Lettere di Vincenzo Rospigliosi cavaliere gerosolimitano e capitano generale dell'armata nella guerra di Candia', Il Muratori. Raccolta di documenti storici inediti o rari tratti dagli archivi italiani pubblici o privati, 3 vols. (Rome: Tipografia Vaticana, 1892-5), 1 (1892), 181-4, and 2 (1893), 167-70; ASV, Segr. Stato, Soldati, 30, 155, 167.

37 ASv, Segr. Stato, Soldati, $127-8$.

38 Asv, Segr. Stato, Particolari, $47-8$. 
their own staff and then informed the pope of the things that they judged most reliable and relevant. However, the former seems to be more in charge of extraordinary affairs and special services, while the latter is more responsible for handling information circulating through the normal channels of the Curia-a division that hardly matches up with the conventional but often improper distinction between official and informal information sources. Cesare Latino was in charge of the mail service between Istanbul, Naples and Madrid for the Spaniards, and probably managed information too, which explains his offer: keeping the cardinal-nephew informed of the progress of the siege of Candia. In respect of the data transmitted, as well as of the means of communication, and even if Latino made his move as a 'private individual', it is highly probable that the Viceroy of Naples himself had authorised it, tacitly or not. There is another indication that the move may have been at least tolerated by the authorities in Naples or even in Madrid, by virtue of the joint effort in the Eastern Mediterranean and on the service of Christianity: in May 1669, Cesare Latino "begs" the cardinal Rospigliosi to share the news sent to him with the Marquis of Astorga, Spain's ambassador in Rome at the time. ${ }^{39}$ The private "particular devotion" Latino shows to the Rospigliosis in the name of his family actually reflects that owed by the King of Spain, the regent Maria Anna of Austria and the Viceroy of Naples to the Supreme Pontiff. ${ }^{40}$ His correspondence is entirely devoted to the subsequent operations, and sounds like the letters and reports by the Venetian officers on duty in the Three Islands. The data Latino provides the Curia happens to fill the blanks in the news disseminated by the Venetian government to its allies, which, because they were the more institutional, are the primary sources. Therefore, the way secondary data produced by a valued but always extra source was used appears quite similar to the handling of the newsletters from Ragusa, and to the role assigned to avvisi pubblici, in a way that is comparable to how present-day intelligence services work with both 'joint' and 'open-source intelligence' (OSINT).

Studying the Secretariat of State of the Holy See's archives clearly shows that the institutional appetite for the handwritten or printed newssheets compiled weekly in Italy grew continuously during the seventeenth century. It can even be suggested that open-source intelligence was invented during the middle decades of the century while chancelleries, after the early sentences against the dissemination of the news and state secrets, and a long period of mistrust towards the novellisti, those Italian newsmen who, at the beginning, were not always differentiated by the authorities from spies or pamphleteers, begin

39 ASv, Segr. Stato, Particolari, 48, 300.

40 ASv, Segr. Stato, Particolari, 47, 196, 13 May 1668. 
consistently to use the media to put to use the data they got from confidential channels. $^{41}$

Given the implication of the Serenissima in the Cretan war, and its resources and contacts in south-eastern Europe and the Levant, it is no surprise that the only newssheet entirely devoted to the operations appeared in Venice during the last phase of the conflict. It is a handwritten periodical dedicated to one and only one matter. Its continuous publication between 1666 and 1669 fed the nuncios, the Secretary of State and the cardinal-nephew's interest. ${ }^{42}$ Moreover, the newssheet strikes surprisingly aggressive, belligerent notes, notes that were till then unknown in Italian media, and exclusively used for the occasional avvisi or printed reports published to relate and celebrate some great event, as for example the victory of Lepanto, almost a century before. The issue of 17 August 1668 begins, for instance, with a very unusual metaphor: "Quanto più il serpe d'Oriente tanta uomitare i suoi toschi sopra la Città di Candia, tanto magg[o]ri incontra gl'ostacoli, ne ad altro seruono le sue stricie, e ritorte, che $\mathrm{p}$ [er] isquamarsi, e restar lordato nel proprio sangue", that is: "The more the Oriental snake tries to vomit his poison on the City of Candia, the higher the obstacles he meets become". ${ }^{43}$ Thus, from a technological point of view, this handwritten newssheet is archaic, while also being in some sense backward-looking in the way it deals with war, events and the Ottoman Empire. The siege of Candia is epically reported. Therefore, the content of public news was still not completely dissimilar to that of the news exchanged between the pope and the Serenissima. The war foglietto was in harmony with the official discourse, news and ideology and thus appeared as another tool of Venetian persuasive force, if not propaganda.

Originally, it was probably an appendix to one of the main periodicals assembled in Venice. When the war began, as 60 years previously, the Avvisi di Venetia still presented the news fresh from Milan, Genoa, Turin, Vienna or France. In May and August 1646, a sort of supplement giving original information about the war was issued, initially on the same day as the main sheet, then a day after. On 4 August, for example, a separate sheet details the seizure of Novigrad by the Ottomans and the projects of general Capello, who had left for Souda on 6 July, at the head of the fleet. ${ }^{44}$ The same newsman undoubtedly

\footnotetext{
41 See Johann Petitjean, 'Mots et pratiques de l'information: ce que aviser veut dire (XVI ${ }^{\mathrm{e}}-\mathrm{XVII}^{\mathrm{e}}$ siècles)', Mélanges de l'Ecole française de Rome (Italie-Méditerranée), 122.1 (2010), pp. 107-21. BAV, Barb. Lat., 6369-6370, 6401-6403; Asv, Segr. Stato, Avvisi, 39; ASv, Segr. Stato, Venezia, 106-8; and, in Venice: Archivio di Stato di Venezia, Inquisitori di Stato, 704.

44 Asv, Segr. Stato, Avvisi, 19, 136-7.
} 
wrote the two sheets, but the phraseology is different. If the original newspaper strictly followed the enunciative model established in the past century, which was based on the standards of data transmission among the different organs of the Venetian government and systems for processing information, that is reporting the facts in the shortest and most neutral way possible, the supplement offered a more heroic tale, which did not refrain from judgement or exhortation, the compiler appealing for instance in February 1647 to "suppress" the Ottoman's "insolence". 45

Between the war of Cyprus and the war of Crete, the European media landscape changed deeply, notably because of the circulation of the Avvisi and gazettes. When the Ottoman troops landed in Crete and the Sultan's armies marched on to the Balkans, the actors of news promotion adapted their production to the specific conditions of the new Ottoman-Venetian war, and to the new Italian and European media context, partly inherited from the Thirty Years War. The content of some media was profoundly modified: the Avvisi di Malta or di Venetia, for instance, gradually became real war newssheets. Pre-existing functions and uses may have changed too. Both the structural plurality of nodes and the ductility of the networks in the specific context of the Cretan war not only reflect in the architecture and contents of the Vatican archive, but also integrate and institutionalise new media. Network functions, operation and management contributed to design early modern information. The Papal network differentiation and hierarchies depended less on the type or geographical location of the data than on the circuit's institutionality. The specific case developed here proves how important it is to illuminate empirically these configurations in their various facets, that is to say not forgetting to interrogate the media, its reception and uses, and to consider the institutions dynamically through the complementarities and/or antagonisms their information policy may reveal. The Rospigliosis' year, for instance, show that some institutional general evolutions, like the growing autonomy of the Secretary of State within the Curia and his strengthening towards the cardinal-nephew, are anything but linear and may be contrasted according to the sphere of activity or the context. Paradoxically, it is when Decio Azzolino, whose faction influenced the Conclave of 1655 that elected Fabio Chigi against the Barberini, supervises an institution previously ruled by Giulio Rospigliosi himself, that the cardinal-nephew's news networks in south-eastern Europe and the Mediterranean are substantially mobilised to verify, complete or even replace the Secretariat's official web, revealing a centralised competitive and profitably flexible dual information system at the Curia.

45 Johann Petitjean, 'Compilation des nouvelles et écriture de l'actualité à Venise au XvI ${ }^{\mathrm{e}}$ siècle', Hypothèses, 13 (2010), pp. 73-82; ASv, Segr. Stato, Avvisi, 20, 40, 14 February 1647. 